\title{
Physiology and production of sesame genotypes BRS-Seda and Preto under organomineral fertilization
}

\author{
Saint-Clear S. e Santos ${ }^{1}$, Pedro D. Fernandes ${ }^{2}$, Messias F. de Queiroz ${ }^{1}$, Nair H. C. Arriel ${ }^{3}$, \\ Victor H. de A. Ribeiro ${ }^{4} \&$ Josely D. Fernandes ${ }^{1}$ \\ ${ }^{1}$ Universidade Estadual da Paraíba. Campina Grande, PB, Brasil. E-mail: saint-clear@hotmail.com (Corresponding author) - ORCID: 0000-0002-2602- \\ 8752; mefiqueiroz@yahoo.com.br - ORCID: 0000-0002-5208-6059; joselysolo@yahoo.com.br - ORCID: 0000-0002-1297-6962 \\ ${ }^{2}$ Universidade Federal de Campina Grande. Campina Grande, PB, Brasil. E-mail: pedrodantasfernandes@gmail.com - ORCID: 0000-0001-5070-1030 \\ ${ }^{3}$ Embrapa Algodão. Campina Grande, PB, Brasil. E-mail: nair.arriel@embrapa.br - ORCID: 0000-0003-3987-9553 \\ ${ }^{4}$ Universidade Federal da Paraíba. Bananeiras, PB, Brasil. E-mail: victor_herbert_cg@hotmail.com - ORCID: 0000-0002-7869-1126
}

\begin{abstract}
Sesame is an oilseed that has low demand of water; it is widely grown in tropical regions, but few studies had been conducted on its mineral nutrition. The objective of this study was to evaluate physiological and production variables of two sesame genotypes (BRS-Seda and Preto) varying the organomineral fertilizer doses, via fertigation. The genotypes were grown under field conditions during the 2014/2015 dry season, in an agricultural area in Lagoa Seca, PB, Brazil. The two genotypes were subjected to five doses $(0,30,60$, 90 and $120 \%$ of the nutritional requirement of the crop) of an organomineral fertilizer based on sugarcane vinasse, and to an additional treatment consisting of mineral fertilizer (100\% of the crop requirement). The experiment was conducted in a randomized block design, in a $(2 \times 5+2)$ factorial arrangement, with 12 treatments and 4 repetitions, totaling 48 plots. Among the physiological variables evaluated, only internal $\mathrm{CO}_{2}$ concentration was affected by the organomineral fertilizer doses. The number of fruits per plant, fruit weight per plant, seed weight per plant, and 1000 seed weight of both cultivars were favored by the organomineral fertilization. The organomineral fertilizer dose of $120 \%$ provided better results for the two sesame genotypes than those found with the mineral fertilization.
\end{abstract}

Key words: Sesamum indicum L., biofertilizer, nutrition

\section{Fisiologia e produção de genótipos de gergelim BRS Seda e Preto submetidos a adubação organomineral}

RESUMO: O gergelim é uma oleaginosa pouco exigente em água, muito cultivada em regiões tropicais, mas com poucos estudos sobre sua nutrição mineral. Neste trabalho, objetivou-se avaliar variáveis fisiológicas e de produção de dois genótipos de gergelim (BRS Seda e Preto), variando as doses de adubação organomineral, via fertirrigação. Os genótipos foram cultivados em condições de campo durante a estação seca de 2014/2015, em área agrícola no município de Lagoa Seca, PB. Os dois genótipos foram submetidos a cinco doses de adubação organomineral (0,30,60, 90 e 120\% da exigência nutricional da cultura), à base de vinhoto de cana-de-açúcar e um tratamento adicional, constituído de adubação mineral (100\% da exigência da cultura), constituindo um fatorial $(2 \times 5+2)$, no delineamento experimental em blocos ao acaso, com 12 tratamentos e quatro repetições, totalizando 48 parcelas. Entre as variáveis fisiológicas, apenas a concentração interna de $\mathrm{CO}_{2}(\mathrm{Ci})$ foi afetada pelas doses de adubação organomineral. O número e massa de frutos por planta, massa de sementes por plantas e massa de 1000 sementes de ambas as cultivares foram favorecidos pela adubação organomineral. A dose de $120 \%$ de adubação organomineral proporcionou aos dois genótipos de gergelim resultados superiores aos alcançados com a adubação mineral.

Palavras-chave: Sesamum indicum L., biofertilizante, nutrição 


\section{INTRODUCTION}

Sesamum indicum L. is one of the main oleaginous plants grown worldwide and one of the first species domesticated by humans; the main product of this species is the seeds, which present high nutritional value as human food and medicinal properties (Queiroga et al., 2009; Asl, 2017). Although sesame production is lower than most oilseeds, it has great potential and can be grown by small and medium producers, since it requires simple agricultural practices (Grilo Júnior \& Azevedo, 2013; Asl, 2017).

Agricultural productions present limitations in the semiarid region of the Brazilian Northeast due to physicalenvironmental peculiarities of this region, such as high evapotranspiration and low soil fertility (Conti, 2005). However, an adequate management of irrigation and fertilization in semiarid areas can increase crop production in the region (Parida \& Das, 2005). Regarding the nutritional aspects, organomineral fertilizers can activate the soil microbiota, accelerate decomposition and humification of dry matter, and improve the soil physical structure by increasing aeration and water retention capacity (Elkholy et al., 2005; Asl, 2017).

Efforts have been directed to the creation and adaptation of technologies that promote increases in crop productivity indexes, focused on the advancement of knowledge in this field, mainly in the Brazilian Northeast region due to its climatic limitations (Beltrão et al., 2013; Grilo Júnior \& Azevedo, 2013).

The objective of this study was to evaluate gas exchange and production variables of two sesame genotypes (BRS-Seda and Preto) subjected to different doses of an organomineral fertilizer based on sugarcane vinasse, via fertigation.

\section{Material ANd Methods}

The experiment was carried out during the 2014/2015 dry season (November to February) under field conditions in a cultivated area of the Centro de Ciências Agrárias e Ambientais (CCAA) of the Universidade Estadual da Paraíba (UEPB) in Lagoa Seca, PB, Brazil (7' 9' S, 35 52' W, and altitude of $634 \mathrm{~m}$ ).

The climate of the region is AS, tropical with dry season, according to the Köppen classification, presenting mean annual air temperature of $22^{\circ} \mathrm{C}\left(19\right.$ to $\left.28^{\circ} \mathrm{C}\right)$. The region presents average annual rainfall over $700 \mathrm{~mm}$, with higher rainfall depths concentrated in April to August; annual evapotranspiration of $500 \mathrm{~mm}$ and average annual relative air humidity of 85\% (Queiroz et al., 2013). During the period of the experiment, the total rainfall was $31 \mathrm{~mm}$.

The experiment was conducted in a randomized block design, with a $2 \times 5+2$ factorial arrangement and 4 repetitions, totaling 48 plots. The factors consisted of two sesame genotypes (BRS-Seda cultivar and Preto line), five organomineral fertilizer doses $(0,30,60,90$ and $120 \%$ of the nutritional requirement of the crop) plus an additional treatment for each genotype using total mineral fertilization $\left(\left(\mathrm{NH}_{4}\right)_{2} \mathrm{SO}_{4}=0.0240 \mathrm{~kg}\right.$, $\mathrm{MAP}=0.0384 \mathrm{~kg}, \mathrm{KNO}_{3}=0.0096 \mathrm{~kg}, \mathrm{ZnSO}_{4}=0.0005 \mathrm{~kg}$, $\mathrm{FeSO}_{4}=0.0065 \mathrm{~kg}, \mathrm{MnSO}_{4}=0.0010 \mathrm{~kg}, \mathrm{CuSO}_{4}=0.0002 \mathrm{~kg}$ and $\mathrm{H}_{3} \mathrm{BO}_{3}=0.0004 \mathrm{~kg}$ ), $100 \%$ of the nutritional requirement of the crop.
The organomineral fertilizer was prepared considering the recommended dose of NPK (50-80-20) for sesame crops, and formulated according to the methodology and nutritional requirements of the species described by Santos et al. (1982) and Cavalcanti (1998). A spreadsheet was developed based on the composition of the different organic ingredients and mineral fertilizers, using the MS-Excel Solver tool (Amlie, 2009).

The preparation of the organomineral solution was carried out in two steps. First, the organic ingredients (vinasse = $161,45 \mathrm{~kg}$, molasses $=20 \mathrm{~kg}$, poultry blood $=5 \mathrm{~kg}$ and milk $=$ $5 \mathrm{~kg}$ ) were mixed with water in a $200 \mathrm{~L}$ container, where they underwent aerobic fermentation. After stabilization, the second step started, with the addition of mineral fertilizers (MAP = $3.70 \mathrm{~kg}, \mathrm{CuSO}_{4}=0.04 \mathrm{~kg}, \mathrm{ZnSO}_{4}=0.08 \mathrm{~kg}, \mathrm{MnSO}_{4}=0.16 \mathrm{~kg}$, $\mathrm{FeSO}_{4}=2.07 \mathrm{~kg} ; \mathrm{H}_{3} \mathrm{BO}_{3}=0.18 \mathrm{~kg}$ and $\left.\left(\mathrm{NH}_{4}\right)_{2} \mathrm{SO}_{4}=2.33 \mathrm{~kg}\right)$, which were mixed until complete solubilization, making a stock solution. The organomineral solution was divided into 12 applications, which were performed every three days from the $15^{\text {th }}$ to the $48^{\text {th }}$ day after emergence (DAE); this period comprised the sesame vegetative growth until the beginning of flowering.

The first irrigation was performed one day before sowing to raise the soil moisture to field capacity. The water volumes of the subsequent irrigations were applied according to the need of the crop, varying the volume according to the reference evapotranspiration (ETo) and climatological water balance, and they were calculated by estimating the crop coefficient (kc) for $1.0(\mathrm{kc}=\mathrm{ETc} / \mathrm{ETo})$. The reference evapotranspiration (ETo) was estimated using the Penman and Monteith (FAO56) methodology (Ortega-Farias et al., 2009). Irrigation was suspended at approximately $80 \mathrm{DAE}$.

The sesame seeds were provided by Embrapa Algodão; they were subjected to a rigorous selection, pre-cleaning and ventilation. The sowing was performed manually, on November 11,2014 , in shallow and continuous grooves of $2 \mathrm{~cm}$ of depth, placing 30 seeds per linear meter and leaving 10 plants $\mathrm{m}^{-1}$ after thinning (Perin et al., 2010). Weeds were controlled manually.

Gas exchange was evaluated using an IRGA (Infra-Red Gas Analyzer, LCpro-SD, ADC Bioscientific, UK) under photosynthetic photon flux density of $1600 \mu \mathrm{mol} \mathrm{m} \mathrm{m}^{-2} \mathrm{~s}^{-1}$. The physiological variables of the sesame plants were evaluated at 50, 65 and 70 DAE, between 08 and 12 hours.

The seeds were harvested as the first fruits were yellowing or changing from green to light brown (Perin et al., 2010). After cutting the plants, the fruits remained inside the greenhouse for 15 to 20 days for complete drying.

The production variables evaluated consisted of number of fruits and fruit weight per plant, seed weight per plant and 1000 seed weight (Suassuna et al., 2017).

The data obtained were subjected to analysis of variance using the SISVAR 5.1 program $(\mathrm{p}<0.05)$ (Ferreira, 2008). When effect of the organomineral fertilizer doses was significant, polynomial regression analysis was applied. The means of the genotypes were compared by the Tukey's test, and orthogonal contrasts with $\mathrm{t}$ test $(\mathrm{p} \leq 0.05$ and $\mathrm{p} \leq 0.01)$ were performed for the factorial versus the additional treatment. 


\section{Results AND Discussion}

The organomineral fertilization had significant effect $(\mathrm{p} \leq 0.05)$ on the internal $\mathrm{CO}_{2}$ concentration (IC) at $65 \mathrm{DAE}$ (Figure 1), without difference between genotypes.

The regression analysis for IC showed that the cubic polynomial model was the most adequate $(\mathrm{p}<0.05)$, with $\mathrm{R}^{2}=0.88$. The maximum IC found was $197.30 \mu \mathrm{mol} \mathrm{mol}^{-1}$, at 65 DAE and with the organomineral fertilizer rate of $22 \%$. The lowest IC found was $164.41 \mu \mathrm{mol} \mathrm{mol}^{-1}$, with the organomineral fertilizer rate of $103.14 \%$.

Similar IC were reported by Suassuna et al. (2017), who evaluated the tolerance of sesame plants under saline stress, using different genotypes; they found a mean IC of $186.14 \mu \mathrm{mol} \mathrm{mol}^{-1}$, with higher IC for the Preto line (mean of 213,26 $\mathrm{mol} \mathrm{mol}^{-1}$ ), and means below $200.00 \mu \mathrm{mol} \mathrm{mol}^{-1}$ for the other genotypes, indicating less photosynthetic activity.

According to Ikejiri (2007), decreases in IC present stomatal limitation, limiting photosynthetic performance, since the greater the stomatal opening the greater the carbon dioxide diffusion to the substomatal chamber. According to Taiz et al. (2015), a greater opening of the stomata favors the entry of $\mathrm{CO}_{2}$ into the leaf mesophyll, increasing its internal concentration

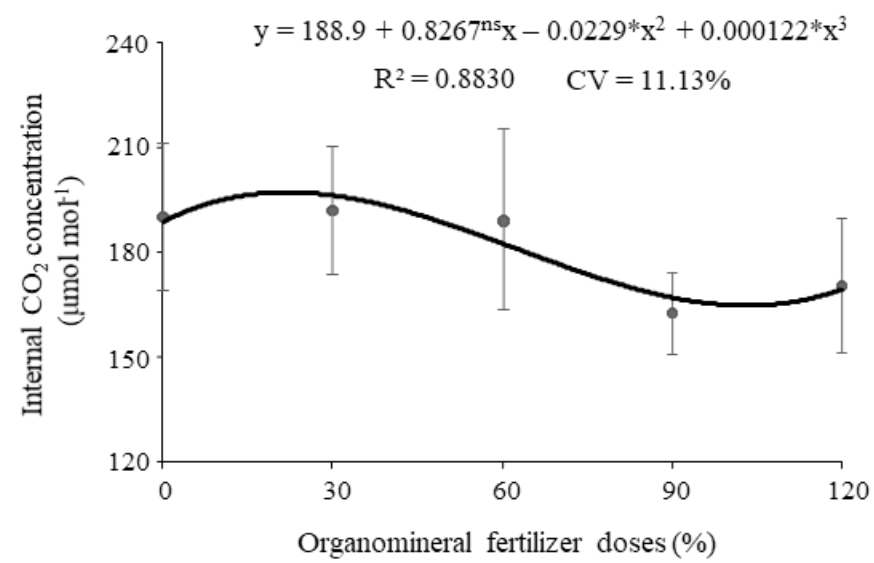

$\mathrm{CV}$ - Coefficient of variation; Significant at $\mathrm{p} \leq 0.05$, and ns - Not significant by F test Figure 1. Internal $\mathrm{CO}_{2}$ concentration in sesame genotypes (BRS-Seda and Preto) subjected to organomineral fertilization

A.

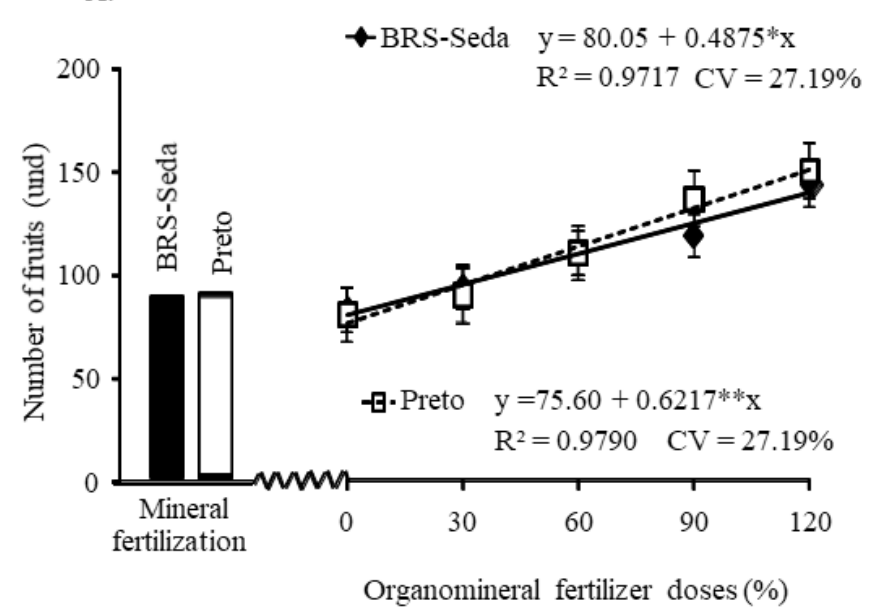

and, consequently, photosynthesis. Thus, the stomatal closure decreases the carbon dioxide assimilation rate.

IC is associated with the production of the plants, since it is the product of the intercepted solar energy and $\mathrm{CO}_{2}$ fixed during a period (Taiz et al., 2015).

Figure 2 shows the results of the regression analysis for number of fruits and fruit weight per plant of the sesame genotypes, with significant $(p<0.05)$ effect of fertilization on these variables in both genotypes, increasing linearly as the organomineral fertilizer doses are increased.

The fruit production of the evaluated genotypes increased due to the use of organomineral fertilizer; the Preto sesame line was the most productive (Figure 2A). The greater fruiting of this line was due to the greater number of branches-expanding the area of fruit production-and the fertilization received.

The BRS-Seda sesame cultivar reached an average of 139 fruits per plant in the treatment with the organomineral fertilizer dose of $120 \%$. The organomineral fertilizer dose of $0 \%$ resulted in an average of 80 fruits. Contrastingly, the average production of the Preto sesame was 150 fruits per plant with the highest organomineral fertilizer dose; this genotype produced an average of 76 fruits with the organomineral fertilizer dose of $0 \%$.

The BRS-Seda and Preto genotypes produced 89 and 91 fruits, respectively, in the additional treatment with $100 \%$ mineral fertilization, denoting the beneficial effect of the organomineral fertilization over the mineral fertilization in the sesame crop.

Similarly, Bharathi et al. (2014) evaluated the effects of different fertilizers on sesame yield and found 37 to 91 fruits per plant; they attributed the results to the increase of the leaf area index, photosynthetic effect, number of secondary and tertiary branches, and increases in production of flowers, responsible for fruit formation. According to Beltrão et al. (2013), the number of fruits per plant is directly related to the number of flowers emitted by the plant.

According to Lima et al. (2013), the interaction between irrigation and biofertilizer increases the sesame productive capacity; they found an average production of 192 fruits per plant when the crop was irrigated with bovine biofertilizer,

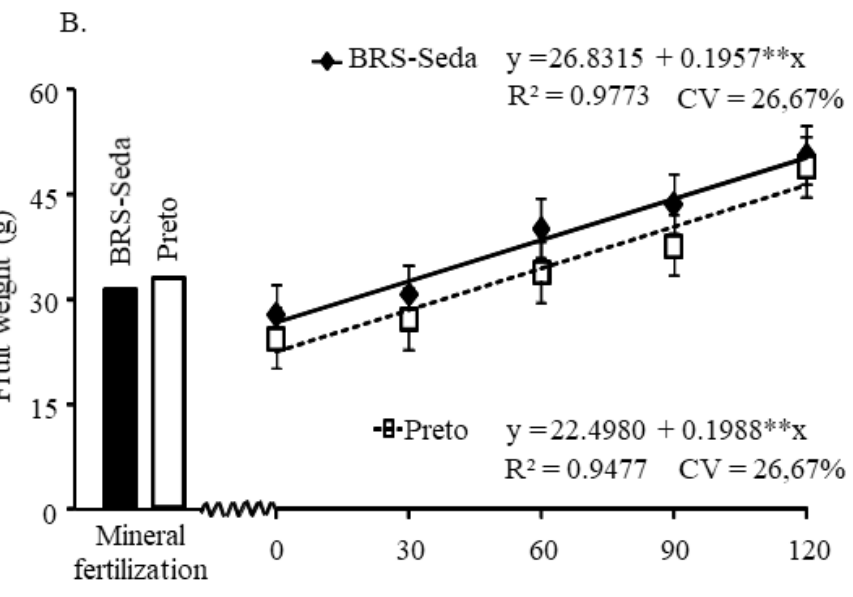

Organomineral fertilizer doses (\%)

$\mathrm{CV}$ - Coefficient of variation; ${ }^{* *}$ - Significant at $\mathrm{p} \leq 0.01{ }^{*}{ }^{-}$Significant at $\mathrm{p} \leq 0.05$ by the $\mathrm{F}$ test

Figure 2. Number of fruits (A.) and fruit weight (B.) per plant of sesame genotypes (BRS-Seda and Preto) subjected to organomineral and mineral fertilizations 
which was higher than that found in absence of the organic fertilizer (148 fruits).

The BRS-Seda cultivar reached an average fruit weight per plant of $50.32 \mathrm{~g}$ in the treatment with the organomineral fertilizer rate of $120 \%$ (Figure $2 \mathrm{~B}$ ), which was higher than the $46.35 \mathrm{~g}$ of fruits found for the Preto line.

The treatment with total mineral fertilization resulted in fruit weight per plant of 31.82 (BRS-Seda) and $33.79 \mathrm{~g}$ (Preto). These results were surpassed by the production found with the organomineral fertilizer doses of 90 and $120 \%$ of the nutritional requirement of the crop. It confirms the positive effect of organomineral fertilization on sesame fruiting, increasing the fruit weight. According to Lima et al. (2013), biofertilizer fertigation is a potential viable source of nutrients and water to sesame plants, increasing the number of fruits, fruit weight, and 1000 seed weight.

Significant effects $(\mathrm{p} \leq 0.05)$ promoted by organomineral fertilization on the sesame seed weight per plant is shown in Figure 3.

The two genotypes showed a linear increase in seed weight, from $15.39 \mathrm{~g}$ (organomineral fertilizer rate of $0 \%$ ) to $27.22 \mathrm{~g}$ (organomineral fertilizer rate of $120 \%$ ) in the BRS-Seda cultivar; and from $12.25 \mathrm{~g}(0 \%)$ to $25.59 \mathrm{~g}(120 \%)$ in the Preto sesame line. Based on the results of seed production per plant, a yield of approximately $2,700 \mathrm{~kg} \mathrm{ha}^{-1}$ was estimated for both genotypes with the dose of $120 \%$ of the organomineral fertilizer based on sugarcane vinasse.

Similarly, Grilo Júnior \& Azevedo (2013) evaluated the effects of irrigation on the development and production of BRS-Seda sesame and found $20.40 \mathrm{~g}$ of seeds per plant at the end of the crop cycle, representing $1,600 \mathrm{~kg} \mathrm{ha}^{-1}$. According to Beltrão et al. (2013), the average yield of- the BRS-Seda sesame cultivar is $1,000 \mathrm{~kg} \mathrm{ha}^{-1}$ and it has the potential to produce more than $2,500 \mathrm{~kg} \mathrm{ha}^{-1}$ of seeds under irrigation and ideal conditions of soil, spacing, and cultural practices.

Bharathi et al. (2014) focused on maximizing sesame production by combining organic and inorganic sources of nutrients and found yields of 541.23 to $1160.75 \mathrm{~kg} \mathrm{ha}^{-1}$ when the two fertilizer sources were applied together. According to Souza et al. (2008), this positive effect may be related to the presence of organic matter in the fertilizers, which benefits the

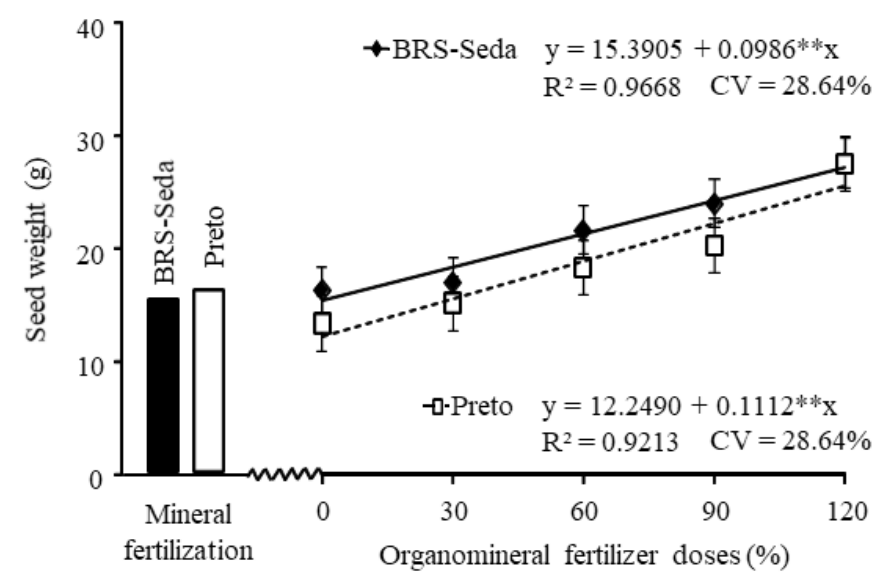

CV - Coefficient of variation; ${ }^{* *}$ - Significant at $\mathrm{p} \leq 0.01{ }^{*}$ - Significant at $\mathrm{p} \leq 0.05$ by the $\mathrm{F}$ test

Figure 3. Seed weight per plant of sesame genotypes (BRSSeda and Preto) subjected to organomineral and mineral fertilizations soil by reducing compaction, increasing water retention, and improving soil structuring.

Similar results were found in the present work for the two evaluated genotypes, when considering the mineral fertilization in the additional treatment. In this treatment, the BRS-Seda cultivar reached a yield of approximately $1700 \mathrm{~kg} \mathrm{ha}^{-1}$, with $17.35 \mathrm{~g}$ of seeds per plant; and the Preto line produced $18.29 \mathrm{~g}$ of seeds per plant, corresponding to yield of $1800 \mathrm{~kg} \mathrm{ha}^{-1}$.

The effect of the treatments on the 1000 seed weight of the sesame genotypes are shown in Figure 4.

The 1000 seed weight of the genotypes reached means of $3.10 \mathrm{~g}$ (BRS-Seda) and $3.02 \mathrm{~g}$ (Preto) with the organomineral fertilizer dose of $120 \%$, with increases of $9.32 \%$ and $9.58 \%$ in relation to the organomineral fertilizer rate of $0 \%$, presenting $2.83 \mathrm{~g}$ (BRS-Seda) and $2.76 \mathrm{~g}$ (Preto). These results confirm the efficiency of the organomineral fertilizer based on sugarcane vinasse because the sesame plants produced a larger weight of seeds as the fertilizer doses were increased.

The additional treatment with total mineral fertilization resulted in 1000 seed weights of $2.87 \mathrm{~g}$ (BRS-Seda) and 2.92 g (Preto).

Jadhav et al. (2015) evaluated nitrogen fertilization on sesame and found 1000 seed weight of $2.87 \mathrm{~g}$. Campos et al. (2014) evaluated biometric characteristics of sesame plants and found 1000 seed weight of $3.8 \mathrm{~g}$ for the BRS-Seda cultivar. According to EMBRAPA (2009), the estimated reference 1000 seed weight for the cultivar BRS-Seda is $3.22 \mathrm{~g}$.

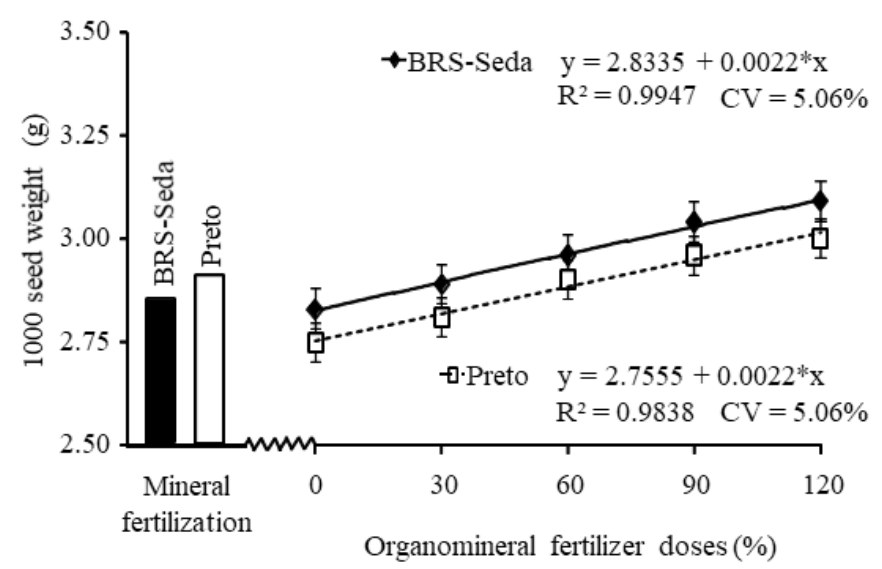

$\mathrm{CV}$ - Coefficient of variation; ${ }^{* *}$ - Significant at $\mathrm{p} \leq 0.01{ }^{*}$ - Significant at $\mathrm{p} \leq 0.05$ by the $\mathrm{F}$ test

Figure 4. 1000 seed weight of sesame genotypes (BRS-Seda and Preto) subjected to organomineral and mineral fertilizations

\section{Conclusions}

1. Among the physiological parameters, only internal $\mathrm{CO}_{2}$ concentration was affected by the organomineral fertilizer doses. The maximum and minimum concentrations observed were 197.30 and $164.41 \mu \mathrm{mol} \mathrm{mol}^{-1}$ corresponding to doses 22 and $103.14 \%$, respectively.

2. The production components number of fruits per plant, fruit weight per plant, seed weight per plant, and 1000 seed weight of the two evaluated cultivars increase with the organomineral fertilizing doses.

3. The organomineral fertilizer rate of $120 \%$ resulted in better results for the sesame genotypes than those obtained with total mineral fertilization. 


\section{Literature Cited}

Amlie, T. T. Constrained optimization problems in cost and managerial accounting: Spreadsheet tools. American Journal of Business Education, v.2, p.11-22, 2009. https://doi.org/10.19030/ ajbe.v2i6.4083

Asl, A. N. Effects of nitrogen and phosphate biofertilizers on morphological and agronomic characteristics of sesame (Sesamum indicum L.). Open Journal of Ecology, v.7, p.101-111, 2017. https:// doi.org/10.4236/oje.2017.72008

Beltrão, N. E. de M.; Ferreira, L. L.; Queiroz, N. L.; Tavares, M. da S.; Rocha, M. do S.; Alencar, R. D.; Porto, V. C. N. O gergelim e seu cultivo no semiárido brasileiro. Natal: IFRN, 2013. 225p.

Bharathi, K.; Panneerselvam, P.; Bhagya, H. P. Effect of clipping and plant growth regulator along with different kinds of fertilizers on yield and yield parameters in sesame (Sesamum indicum L.) during monsoon period. Indian Journal of Agricultural Research, v.48, p.232-236, 2014. https://doi.org/10.5958/j.0976-058X.48.3.039

Campos, L. N.; Guilherme, M. de F. de S.; Oliveira, H. M. de; Costa, V. de F.; Silva, E. da. Avaliação biométrica de sementes de Sesamum indicum L. In: Congresso Nordestino de Biólogos, 4, 2014, João Pessoa. Anais... João Pessoa: CONGREBIO, 2014. p.145-147.

Cavalcanti, F. J. A. Recomendações de adubação para o Estado de Pernambuco: 2.aprox. 2.ed. rev. Recife: Instituto Agronômico de Pernambuco, 1998. 198p.

Conti, J. B. A questão climática do Nordeste brasileiro e os processos de desertificação. Revista Brasileira de Climatologia, v.1, p.7-14, 2005. https://doi.org/10.5380/abclima.v1i1.25226

Elkholy, M. A.; Ashly, S. E.; Gomaa, A. M. Biofertilizer of maize crop and its impact on yield and grain nutrient under low rates of mineral fertilizers. Journal of Applied Science Research, v.2, p.117-121, 2005.

EMBRAPA - Empresa Brasileira de Pesquisa Agropecuária. Gergelim "BRS Seda". Campina Grande: Embrapa Algodão, 2009. 2p.

Ferreira, D. F. SISVAR: Um programa para análise de ensino de estatística. Revista Científica Symposium, v.6, p.36-41, 2008.

Grilo Júnior, J. A. S.; Azevedo, P. V. de. Crescimento, desenvolvimento e produtividade do gergelim 'BRS Seda' na agrovila de Canudos, em Ceará Mirim (RN). Revista Holos, v.2, p.19-33, 2013. https:// doi.org/10.15628/holos.2013.1223

Ikejiri, L.; Camilli, L.; Klein, J.; Rodrigues, J. D.; Boaro, C. S. F. Avaliação da limitação estomática e mesofílica da assimilação de $\mathrm{CO}_{2}$ em girassol ornamental cultivado com lodo de esgoto. Revista Brasileira de Biociências, v.5, p.855-857, 2007.
Jadhav, S. R.; Naiknaware, M. D.; Pawar, G. R. Effect of nitrogen, phosphorus and biofertilizers on growth, yield and quality of summer sesamum (Sesamum indicum L.). International Journal of Tropical Agriculture, v.33, p.475-480, 2015.

Lima, F. A.; Sousa, G. G.; Viana, T. V. A.; Pinheiro Neto, L. G.; Azevedo, B. M.; Carvalho, C. M. Irrigação da cultura do gergelim em solo com biofertilizante bovino. Revista Brasileira de Agricultura Irrigada, v.7, p.102-111, 2013. https://doi.org/10.7127/rbai.v7n200007

Ortega-Farias, S.; Irmak, S.; Cuenca, R. Special issue on evapotranspiration measurement and modeling. Irrigation Science, v.28, p.1-3, 2009. https://doi.org/10.1007/s00271-009-0184-x

Parida, A. K.; Das, A. B. Salt tolerance and salinity effects on plants: A review. Ecotoxicology and Environmental Safety, v.60, p.324-349, 2005. https://doi.org/10.1016/j.ecoenv.2004.06.010

Perin, A.; Cruvinel, D. J.; Silva, J. W. Desempenho do gergelim em função da adubação NPK e do nível de fertilidade do solo. Acta Scientiarum. Agronomy, v.32, p.93-98, 2010. https://doi. org/10.4025/actasciagron.v32i1.2521

Queiroga, V. de P.; Gondim, T. M. de S.; Queiroga, D. A. N. Tecnologias sobre operações de semeadura e colheita para a cultura do gergelim (Sesamum indicum L.). Revista Agro@mbiente On-line, v.3, p.106-121, 2009. https://doi.org/10.18227/1982-8470ragro. v3i2.272

Queiroz, M. F. de; Fernandes, P. D.; Dantas Neto, J.; Arriel, N. H. C.; Marinho, F. J. L.; Leite, S. F. Crescimento e fenologia de espécies de Jatropha durante a estação chuvosa. Revista Brasileira de Engenharia Agrícola e Ambiental, v.17, p.405-411, 2013. https:// doi.org/10.1590/S1415-43662013000400008

Santos, R. A.; Haag, H. P.; Minami, K. Nutrição mineral do gergelim (Sesamum indicum L): II - Concentração e acúmulo de micronutrientes em condições de campo. Anais da Escola Superior de Agricultura “Luiz de Queiroz", v.39, p.995-1018, 1982. https:// doi.org/10.1590/S0071-12761982000200021

Souza, J. O.; Medeiros, J. F. M.; Silva, M. C. C.; Almeida, A. H. B. Adubação orgânica, manejo de irrigação e fertilização na produção de melão amarelo. Horticultura Brasileira, v.26, p.15-18, 2008. https://doi.org/10.1590/S0102-05362008000100003

Suassuna, J. F.; Fernandes, P. D.; Brito, M. E. B.; Arriel, N. H. C.; Melo, A. S.; Fernandes, J. D. Tolerance to salinity of sesame genotypes in different phenological stages. American Journal of Plant Sciences, v.8, p.1904-1920, 2017. https://doi.org/10.4236/ajps.2017.88129

Taiz, L.; Zeiger, E.; Møller, I. M.; Murphy, A. Plant physiology and development. 6.ed. Sunderland: Sinauer Associates Inc., 2015. $761 \mathrm{p}$. 